\title{
Use of thiosemicarbazone and para-nitrobenzoic acid in screening tests for anonymous mycobacteria
}

\author{
JOHN D. BARRIE \\ From the Sectoral Bacteriological Laboratory, Victoria Infirmary, Glasgow
}

SYNOPSIS In screening for anonymous mycobacteria the use of thiosemicarbazone $(10 \mu \mathrm{g} . / \mathrm{ml}$.) may give rise to false positive results. Although these can usually be overcome by further tests, additional time and effort is required, which seriously limits the value of thiosemicarbazone as a true screening agent. Para-nitrobenzoic acid $(500 \mu \mathrm{g} . / \mathrm{ml}$.) has proved more satisfactory in our hands; no false positive results have been obtained and it has the additional advantage that strains of $M$. kansasii (usually thiosemicarbazone sensitive) are resistant to para-nitrobenzoic acid.

In recent years there has been increasing interest in human infections with mycobacteria other than $M$. tuberculosis and various tests have been suggested to enable laboratories to recognize such strains. As almost all anonymous mycobacteria are resistant to one or more of the standard anti-tuberculosis drugs it is of particular importance that they should be separated from drug-resistant strains of $M$. tuberculosis. When, in 1963, the Western Regional Hospital Board established a reference laboratory to maintain a register of patients in the west of Scotland who were excreting drug-resistant mycobacteria, one of its first tasks was to undertake such a classification. The screening procedure suggested by Marks and Trollope (1960) has the advantage of speed and technical simplicity and has been used in conjunction with each sensitivity test performed by this laboratory. Any strain fulfilling two of the following four criteria is worthy of special investigation: (1) atypical morphology; (2) pigment production when incubated in artificial light; (3) growth when incubated at $25^{\circ} \mathrm{C}$.; (4) growth on Lowenstein-Jensen medium containing $10 \mu \mathrm{g} . / \mathrm{ml}$. p-acetamido benzaldehyde thiosemicarbazone.

Although it was found relatively straightforward to recognize pigment production or growth at $25^{\circ} \mathrm{C}$. difficulty was often encountered in deciding what constituted atypical morphology, and the wellrecognized pleomorphism of the tubercle bacillus must inevitably make this so. Furthermore, re-

Received for publication 1 September 1966.

'Present address: Victoria Hospital, Kirkcaldy, Fife. sistance to $10 \mu \mathrm{g} . / \mathrm{ml}$. thiosemicarbazone was encountered rather more frequently than had been expected in an area where the incidence of anonymous mycobacteria was thought to be low (Mitchison, 1962), and for these reasons a more detailed investigation of such strains, and of the patients from whom they were derived, was made.

In this paper are recorded 10 strains of $M$. tuberculosis resistant to thiosemicarbazone, seven of them probably not as a result of previous treatment with this drug. This finding has made us cautious in our interpretation of the results of this part of the screening test for anonymous mycobacteria, and further experience has led us to prefer para-nitrobenzoic acid (Marks, 1965; Tsukamura and Tsukamura, 1964) to thiosemicarbazone for this purpose.

\section{METHODS}

Thiosemicarbazone was dissolved in formamide (which was itself shown to have no inhibitory effect on mycobacteria) and added to Lowenstein-Jensen medium (Mackie and McCartney, 1960) to give a final concentration of $10 \mu \mathrm{g} . / \mathrm{ml}$.

Para-nitrobenzoic acid was dissolved in sodium hydroxide and added to Lowenstein-Jensen medium to a final concentration of $500 \mu \mathrm{g} . / \mathrm{ml}$.

The inoculum was prepared by placing $2 \mathrm{mg}$. moist weight of a young, pure culture of $M$. tuberculosis in $0.4 \mathrm{ml}$. sterile distilled water with six glass beads, and agitating on a Kahn shaker till a homogeneous suspension resulted. One standard loopful $(3 \mathrm{~mm}$. external diameter 24 S.W.G. nichrome wire) was spread evenly over the 
surface of the medium before incubation for three weeks in the dark at $37^{\circ} \mathrm{C}$. The organism was considered resistant to either drug if confluent growth or innumerable discrete colonies developed.

\section{RESULTS}

Of 2,900 different strains tested, 17 showed resistance to $10 \mu \mathrm{g} . / \mathrm{ml}$. thiosemicarbazone and seven of these were accepted as genuine anonymous strains on the basis of additional tests. The remaining 10 organisms failed to show any evidence other than thiosemicarbazone resistance that they might be anonymous strains. These were titrated in doubling dilutions of the drug prepared in Lowenstein-Jensen medium in the same way as before and the end-points are shown in Table I. All were tested for animal pathogenicity by injecting $2 \mathrm{mg}$. moist weight of the culture intraperitoneally into guinea-pigs weighing $250 \mathrm{~g}$. Most anonymous mycobacteria have reduced virulence for guinea-pigs, but in the present work the picture has been complicated by the fact that many of the strains tested were resistant also to isoniazid and consequently were likely to be relatively avirulent to guinea-pigs.

Good growth of all cultures was obtained at $37^{\circ} \mathrm{C}$.; none grew at $25^{\circ} \mathrm{C}$. or at $45^{\circ} \mathrm{C}$. All were niacin positive.

Table I contains details of the drug-sensitivity patterns of the strains tested and their animal pathogenicity, and the age, sex, and duration of disease in the patients from whom the organisms were cultured. Where ascertainable, previous treatment with thiosemicarbazone has been recorded; specific enquiries were directed to find out whether any of the drug's analogues had been exhibited, e.g., Thiacetazone, Tebafen, Neustab, Benzthiozone, Bercillon A, Thioparamizone.

When the test employing para-nitrobenzoic acid became available these 17 strains were retested for susceptibility to this drug. The seven genuine anonymous strains proved resistant to it; the other 10 were sensitive.

\section{DISCUSSION}

During 1963-64 the use of thiosemicarbazone (T.S.C.) was helpful in detecting seven strains of anonymous mycobacteria, but in a slightly larger number 'false positive' results were obtained. As nine of these 10 strains showed resistance to strepto-

TABLE I

RESULTS IN 10 STRAINS TESTED

\begin{tabular}{|c|c|c|c|c|c|c|c|c|c|c|c|}
\hline \multirow{3}{*}{$\begin{array}{l}\text { Sex } \\
\text { Age }\end{array}$} & \multirow{3}{*}{$\begin{array}{l}\text { Years } \\
\text { since } \\
\text { First } \\
\text { Notified }\end{array}$} & \multicolumn{6}{|l|}{ Antibiotic } & \multirow{3}{*}{$\begin{array}{l}\text { Previous } \\
\text { Thiosemicarbazone } \\
\text { (T.S.C.) History }\end{array}$} & & & \multirow{3}{*}{ Guinea-pig Findings } \\
\hline & & \multirow{2}{*}{$\begin{array}{l}\text { Strepto- } \\
\text { mycin }\end{array}$} & \multirow{2}{*}{ P.A.S. } & \multirow{2}{*}{ I.N.A.H. } & \multirow{2}{*}{$\begin{array}{l}\text { Vio- } \\
\text { mycin }\end{array}$} & \multirow{2}{*}{$\begin{array}{l}\text { Cyclo- } \\
\text { serine }\end{array}$} & \multirow{2}{*}{$\begin{array}{l}\text { Ethiona- } \\
\text { mide }\end{array}$} & & \multicolumn{2}{|c|}{$\begin{array}{l}\text { Thiosemicarbazone } \\
\text { Titration }\end{array}$} & \\
\hline & & & & & & & & & Resistant & Sensitive & \\
\hline $\begin{array}{l}M \\
62\end{array}$ & 2 & $\mathbf{R}$ & $\mathbf{S}$ & $\mathbf{R}$ & $\mathbf{S}$ & $\mathbf{S}$ & $\mathbf{S}$ & None & 20 & 40 & $\begin{array}{l}\text { Died } 25 \text { days; } \\
\text { extensive disease }\end{array}$ \\
\hline $\begin{array}{l}\mathbf{M} \\
58\end{array}$ & 15 & $\mathbf{S}$ & $\mathbf{R}$ & $\mathbf{R}$ & $\mathbf{S}$ & $\mathbf{S}$ & $\mathbf{S}$ & Had T.S.C. in past & 10 & 20 & $\begin{array}{l}\text { Sacrificed } 90 \text { days; } \\
\text { limited disease }\end{array}$ \\
\hline $\begin{array}{l}F \\
45\end{array}$ & 15 & $\mathbf{R}$ & $\mathbf{S}$ & $\mathbf{R}$ & $\mathbf{S}$ & $\mathbf{S}$ & $\mathbf{S}$ & $\begin{array}{l}\text { No record of T.S.C. } \\
\text { at any time }\end{array}$ & 160 & - & $\begin{array}{l}\text { Sacrificed } 90 \text { days; } \\
\text { extensive disease }\end{array}$ \\
\hline $\begin{array}{l}\mathbf{F} \\
33\end{array}$ & 19 & $\mathbf{R}$ & $\mathbf{R}$ & $\mathbf{R}$ & $\mathbf{S}$ & $\mathbf{s}$ & $\mathbf{R}$ & None & 20 & 40 & $\begin{array}{l}\text { Died } 24 \text { days; } \\
\text { extensive disease }\end{array}$ \\
\hline $\begin{array}{l}\mathbf{M} \\
39\end{array}$ & 11 & $\mathbf{R}$ & $\mathbf{R}$ & $\mathbf{S}$ & $\mathbf{S}$ & $\mathbf{S}$ & $\mathbf{R}$ & None & 40 & 80 & $\begin{array}{l}\text { Died } 32 \text { days; } \\
\text { extensive disease }\end{array}$ \\
\hline $\begin{array}{l}F \\
38\end{array}$ & 4 & $\mathbf{R}$ & $\mathbf{R}$ & $\mathbf{R}$ & $\mathbf{S}$ & $\mathbf{S}$ & $\mathbf{S}$ & None & 10 & 20 & $\begin{array}{l}\text { Sacrificed } 90 \text { days; } \\
\text { no gross disease }\end{array}$ \\
\hline $\begin{array}{l}\mathbf{F} \\
34\end{array}$ & 6 & $\mathbf{S}$ & $\mathbf{S}$ & $\mathbf{S}$ & $\mathbf{S}$ & $\mathbf{S}$ & $\mathbf{R}$ & $\begin{array}{l}\text { May have had } \\
\text { T.S.C. in past }\end{array}$ & 20 & 40 & $\begin{array}{l}\text { Died } 38 \text { days; } \\
\text { extensive disease }\end{array}$ \\
\hline $\begin{array}{l}M \\
64\end{array}$ & 11 & $\mathbf{R}$ & $\mathbf{S}$ & $\mathbf{R}$ & $\mathbf{S}$ & $\mathbf{S}$ & $\mathbf{R}$ & $\begin{array}{l}\text { No T.S.C. since } \\
1956 ; 1953-56 \\
\text { not traced }\end{array}$ & 10 & 20 & $\begin{array}{l}\text { Sacrificed } 90 \text { days; } \\
\text { no gross disease }\end{array}$ \\
\hline $\begin{array}{l}\mathbf{M} \\
\mathbf{3 1}\end{array}$ & 6 & $\mathbf{R}$ & $\mathbf{S}$ & $\mathbf{R}$ & $\mathbf{S}$ & $\mathbf{S}$ & $\mathbf{R}$ & None & 10 & 20 & $\begin{array}{l}\text { Sacrificed } 90 \text { days; } \\
\text { limited disease }\end{array}$ \\
\hline $\begin{array}{l}F \\
40\end{array}$ & 12 & $\mathbf{R}$ & $\mathbf{R}$ & $\mathbf{R}$ & $\mathbf{S}$ & $\mathbf{S}$ & $\mathbf{S}$ & None & 10 & 20 & $\begin{array}{l}\text { Died } 30 \text { days; } \\
\text { extensive lesions }\end{array}$ \\
\hline
\end{tabular}


mycin, P.A.S., or isoniazid the possibility was entertained that other drugs might have been used in the patient's treatment. Particularly relevant here is the role of ethionamide, in view of the complex cross-resistance which exists between this drug and thiosemicarbazone. The factors involved in this cross-resistance have been discussed at length by Rist (1964), but it has been our experience that, at the critical levels ${ }^{1}$ employed, this cross-resistance is not complete. Five of the 10 thiosemicarbazoneresistant strains were sensitive to ethionamide, and in a number of instances (unpublished) we have recorded ethionamide resistance in strains susceptible to thiosemicarbazone.

Furthermore, it is seldom possible to decide in the laboratory whether a strain's resistance to thiosemicarbazone is innate and probably indicative of an anonymous mycobacterium, or acquired as a result of therapy with thiosemicarbazone (or allied compound) or even ethionamide. This is undoubtedly a significant handicap in its use as a screening test.

Encouraged by the fact that susceptibility to para-nitrobenzoic acid correctly classified the 10

${ }^{1}$ Resistance to T.S.C. - as defined in the text.

Resistance to ethionamide-indicated by test strain having resistance ratio of 8 or more compared with $H 37 \mathrm{Rv}$. under identical conditions strains whose status had been in doubt we incorporated this test in our screening procedure as a substitute for thiosemicarbazone. A further 1,100 strains have now been tested; eight were resistant to para-nitrobenzoic acid, and these all proved, on further tests, to be anonymous strains. No false positive results were obtained. An additional advantage is that strains of $M$. kansasii have proved resistant to para-nitrobenzoic acid, whereas they were sensitive to thiosemicarbazone.

I am grateful to Dr. L. G. Bruce, consultant bacteriologist, for his advice during the preparation of this paper. The clinical information included in Table I was supplied by the following consultant chest physicians: Drs. J. Campbell, J. Cuthbert, J. E. Geddes, A. Lees, and R. Sinclair Kennedy; to them all I express my thanks.

\section{REFERENCES}

Mackie, T. J., and McCartney, J. E. (1960). Handbook of Bacteriology, edited by $R$. Cruickshank, 10 th ed., p. 212. Livingstone, Edinburgh and London.

Marks, J. (1965). Mth. Bull. Minist. Hlth Lab. Serv., 24, 2.

- , and Trollope, D. R. (1960). Tubercle, 41, 133.

Mitchison, D. A. (1962). Ibid., 43, suppl., p. 72, discussion on anonymous mycobacteria.

Rist, N. (1964). In Chemotherapy of Tuberculosis, edited by V. C Barry, p. 210. Butterworths, London.

Tsukamura, M., and Tsukamura, S. (1964). Tubercle, 45, 64. 